\title{
Gerakan Literasi Sains melalui Pengenalan STEAM pada Anak di Komunitas "Panggon Moco" Gresik
}

\author{
Wahyu Kyestiati Sumarno ${ }^{1 *}$, Ali Shodikin ${ }^{2}$, Adinda Aulia Rahmawati ${ }^{3}$, \\ Putri Dian Shafira ${ }^{4}$, Nur Imro'atus Solikha ${ }^{5}$ \\ Universitas Pembangunan Nasional ${ }^{3,4,5}$, Universitas Islam Darul Ulum ${ }^{2}$ \\ wahyu.kyestiati.ds@upnjatim.ac.id ${ }^{1}$, alishodikin@unisda.ac.id ${ }^{2}$,20083010009@ student.upnjatim.ac.id ${ }^{3}$, \\ 20082010106@student.upnjatim.ac.id ${ }^{4}, 20082010014 @$ student.upnjatim.ac.id ${ }^{5}$
}

\begin{abstract}
Scientific literacy is one of the important literacies that children need to have. However, there are many findings that show the low level of scientific literacy in Indonesian children. "Panggon Moco" is one of the reading park communities (TBM) which was formed due to the community's concern for the success of the literacy program. Until now, the literacy developed by this community is still limited to reading literacy. Therefore, it is necessary to develop other literacy such as scientific literacy. A learning approach that has been proven to improve scientific literacy in children is STEAM (science, technology, engineering, art, and mathematics). To answer this challenge, it is necessary to carry out a scientific literacy activities for children in the Panggon Moco community. The method of implementing this program includes several activities, namely (1) discussion and equalization of perceptions; (2) making Fun STEAM Lab books; (3) the STEAM experiment; and (4) STEAM literacy assistance. This activity is carried out offline and online. The results obtained from this program are increasing children's understanding of STEAM and increasing students' interest and motivation in learning.
\end{abstract}

Keywords: scientific literacy; STEAM; Panggon Moco.

\begin{abstract}
Abstrak
Literasi sains merupakan salah satu literasi penting yang perlu dimiliki anak. Namun demikian, banyak temuan yang menunjukkan rendahnya literasi sains pada anak Indonesia. "Panggon Moco" merupakan salah satu taman baca masyarakat (TBM) yang terbentuk atas kepedulian masyarakat untuk menyukseskan program literasi. Hingga kini, literasi yang dikembangkan komunitas ini masih terbatas pada literasi baca. Oleh karena itu, perlu dikembangkan literasi lain seperti literasi sains. Pendekatan pembelajaran yang terbukti meningkatkan literasi sains pada anak adalah pembelajaran STEAM (science, technology, engineering, art, and mathematics). Untuk menjawab tantangan ini, perlu dilakukan gerakan literasi sains pada anak-anak di Komunitas Panggon Moco. Metode pelaksanaan program ini meliputi beberapa kegiatan, yakni (1) diskusi dan penyamaan presepsi; (2) pembuatan buku Fun STEAM Lab; (3) eksperimen STEAM; dan (4) pendampingan literasi STEAM. Kegiatan ini dilakukan secara luring dan daring. Hasil yang diperoleh dari program ini adalah meningkatnya pemahaman anak-anak tentang STEAM dan meningkatkan minat dan motivasi belajar siswa.
\end{abstract}

Kata Kunci: literasi sains; STEAM; Panggon Moco.

702

This is an open access article under the CC-BY SA license 


\section{A. PENDAHULUAN}

Saat ini, gerakan literasi menjadi salah satu program prioritas pemerintah melalui Kemendikbud untuk mengatasi masalah rendahnya tingkat literasi dan ketidakmerataan pendidikan di Indonesia. Salah satu rujukan yang digunakan pemerintah untuk mengukur kemampuan literasi di Indonesia adalah hasil riset Programme for International Student Assessment (PISA) yang merupakan studi internasional empat tahunan tentang prestasi literasi membaca, matematika, dan sains pada siswa sekolah (OECD, 2019). Hasil perolehan Indonesia yang terbaru yakni tahun 2018 baik pada prestasi literasi membaca, matematika, dan sains merosot dibandingkan hasil tahun 2012 (OECD, 2019).

Untuk prestasi literasi sains, hasil PISA tahun 2018 menempatkan Indonesia pada peringkat 70 dari 78 negara dengan skor 396 yang jauh di bawah skor rata-rata prestasi literasi sains seluruh negara OECD yakni 489. Hasil ini menunjukkan bahwa literasi sains siswa di Indonesia masih sangat rendah. Senada dengan hasil ini, beberapa peneliti melaporkan rendahnya capaian literasi sains pada anak di tingkat sekolah dasar dan sekolah menengah di Indonesia (Hasasiyah, dkk., 2020; Hidayah, dkk., 2019; Huryah, dkk., 2017; Nofiana, 2017; Nofiana \& Julianto, 2018). Sedangkan pada tingkat perguruan tinggi, kemampuan literasi sains hanya pada kategori cukup (Fazilla, 2016; Novitasari, 2018).

Program pembelajaran yang terbukti efektif dalam meningkatkan literasi sains pada anak adalah pembelajaran STEAM (Science, Technology, Engineering, Art and Mathematics). Hal ini terlihat dari banyaknya penelitian yang merekomendasikan pembelajaran ini (Imaduddin, 2017; Limbong, dkk., 2019; Munawar, dkk., 2019; Nugraheni, 2019; Nurhikmayati, 2019; Sadiah \& Lestari, 2020). Oleh karena itu, penting untuk dilakukan pembelajaran STEAM melalui gerakan literasi sains bagi anak-anak untuk meningkatkan kemampuan literasi mereka dalam menghadapi tantangan abad 21.

Pelaksanaan program pembelajaran tidak hanya bisa dilakukan di kelas. Berbagai gerakan seperti taman baca masyarakat (TBM) menjadi salah satu pendukung penting untuk menyukseskan gerakan literasi di masyarakat. "Panggon Moco" merupakan salah satu TBM yang terbentuk atas kepedulian masyarakat menyukseskan program literasi di masyarakat. TBM ini terletak di Dusun Pancaran, Desa Siwalan, Kecamatan Panceng, Kabupaten Gresik. "Panggon Moco" sebenarnya memiliki posisi yang sangat strategis di masyarakat Desa Siwalan dalam hal penyuksesan program literasi. Namun demikian, literasi yang dikembangkan masih terbatas literasi baca pada anak. Seharusnya perlu dikembangkan literasi yang lebih maju untuk mendukung literasi di banyak bidang diantaranya literasi sains. Untuk menjawab tantangan ini, kami dari tim Abdimas UPN Veteran Jawa Timur berinisiatif untuk melakukan gerakan literasi sains pada anak di Komunitas Panggon Moco, Gresik.

\section{B. PELAKSAAAN DAN METODE}

Gerakan literasi sains yang dilakukan melalui pengenalan STEAM pada Anak di Komunitas "Panggon Moco" antara lain dengan melakukan eksperimen-eksperimen sederhana dan edukatif yang memuat sains (science), teknologi (technology), teknik 
(eingeneering), seni (art), dan matematika (mathematics). Sasaran program ini adalah anak-anak, pengurus maupun relawan "Panggon Moco" yang berada di Desa Siwalan Kecamatan Panceng Kabupaten Gresik. Program ini muncul sebagai jawaban dari masalah pengembangan program "Panggon Moco" yang masih mandek di literasi baca-tulis, sehingga perlu dikembangkan literasi di bidang lainnya yakni literasi sains.

Secara keseluruhan, pelaksanaan program ini meliputi beberapa kegiatan, yakni (1) diskusi dan penyamaan presepsi; (2) pembuatan buku Fun STEAM Lab; (3) eksperimen STEAM; dan (4) pendampingan literasi STEAM.

\section{HASIL DAN PEMBAHASAN}

Serangkaian program kegiatan literasi sains ini dilaksanakan pada bulan Mei Agustus 2021 secara luring dan daring. Sebanyak 31 siswa dan 5 orang pengurus "Panggon Moco" berpartisipasi dalam serangkaian program ini. Kegiatan yang dilaksanakan secara luring dilakukan dengan protokol kesehatan yang ketat, seperti mencuci tangan, memakai masker, dan menjaga jarak. Hal ini dikarenakan pelaksanaan kegiatan dilakukan pada masa pandemi Covid-19, sehingga berlaku aturan physical and social distancing. Sedangkan kegiatan yang dilakukan secara daring dilakukan menggunakan peranti Google Meet dan WhatApp Group.

\section{Diskusi dan Persamaan Persepsi}

Diskusi dan persamaa persepsi dilakukan oleh tim pelaksana dengan pengurus "Panggon Moco". Diskusi dan penyamaan presepsi dilakukan dalam rangka mencari solusi dari permasalahan yang telah teridentifikasi. Hal ini juga dimaksudkan untuk menghindari konflik apabila solusi alternatif diimplementasikan.

Kegiatan diskusi dan persamaan persepsi dilakukan secara daring dan luring.

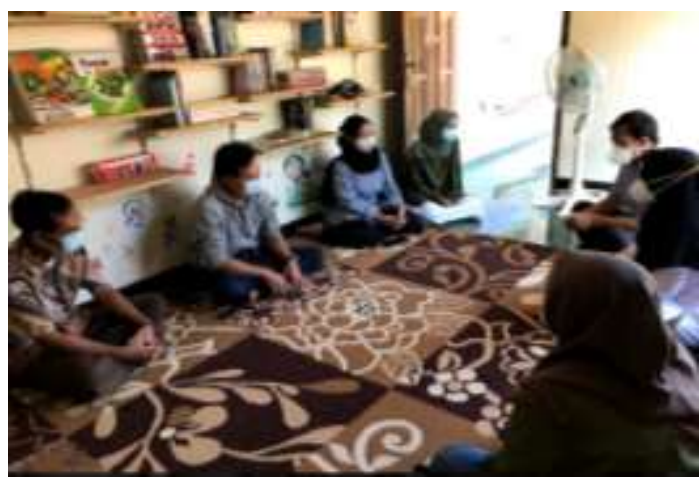

Gambar 1. Diskusi dan Persamaan Persepsi

Dalam kegiatan ini diperoleh kesepatakan antara tim pelaksana dengan mitra dalam bentuk komitmen partisipasi. Bentuk partisipasi mitra antara lain adalah:

a. Bersedia berdiskusi dan berpartisipasi aktif bersama tim pelaksana dalam pelaksanaan kegiatan eksperimen STEAM dan pelatihan dan pendampingan STEAM.

b. Ikut memberikan saran dan masukan dalam pelaksanaan demonstrasi eksperimen.

c. Menyiapkan satu anggotanya untuk dilatih sebagai pendamping untuk keberlanjutan program gerakan literasi STEAM.

d. Bersedia bekerjasama secara berkelanjutan.

\section{Pembuatan Buku Fun STEAM Lab}

Salah satu luaran dalam program pengabdian masyarakat ini berupa buku yang terbitan ber-ISBN dengan judul "Fun STEAM Lab (Percobaan STEAM Sederhana di Rumah). Buku ini berisi penjelasan tentang apa itu STEAM, pentingnya STEAM, protokol keselamatan, dan berbagai eksperimen sains sederhana dan 
menarik yang bisa dilakukan anak-anak di rumah seperti generate electricity from potato, blowing candles with $\mathrm{CO}$, make your own water pump, rainbow in the glass, inflating balloon automatically, dan 20 eksperimen lainnya.

Buku ini ditulis dalam dua bahasa (bilingual): bahasa Indonesia dan bahasa Inggris. Diharapkan melalui buku ini selain belajar sains, anak-anak juga akan belajar kosakata-kosakata baru dalam bahasa inggris. Di dalamnya tersaji langkahlangkah eksperimen yang detail sehingga anak-anak bisa langsung mempraktikkannya di rumah. Buku ini juga memberikan penjelasaan mengenai apa yang akan terjadi dan alasannya berdasarkan ilmu sains. Tentu ini akan mendorong rasa ingin tahu dan berpikir lebih kritis anak. Anak-anak lebih cerdas dan mudah dalam menyelesaikan masalah dalam kehidupan sehari-hari.

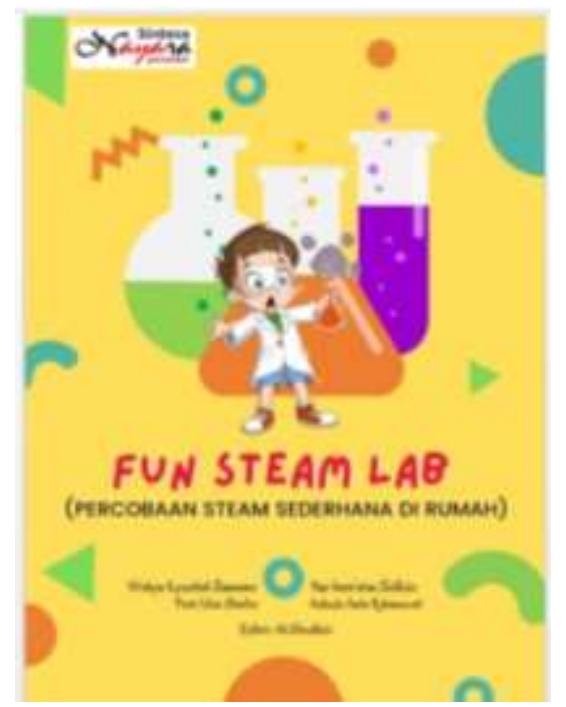

Gambar 2. Luaran buku "Fun STEAM Lab"

Buku ini digunakan oleh anak-anak di komunitas Panggon Moco sebagai panduan percobaan STEAM. Buku ini juga diperbanyak dan dimasukkan ke dalam koleksi di perpustakaan "Panggon Moco".

\section{Eksperimen STEAM}

Pelaksanaan eksperimen STEAM dilakukan secara luring dengan protokol kesehatan yang ketat. Pelaksanaan secara luring ini atas masukan, pertimbangan dan kesepakatan antara tim pelaksana dengan pengurus "Panggon Moco". Peserta yang mengikuti juga atas ijin orang tua dan sudah dipastikan tidak sedang sakit dan tidak terpapar Covid-19.

Eksperimen STEAM ini dimulai dengan pemaparan materi yang menjelaskan tentang apa itu STEAM dan pentingnya STEAM. Kegiatan selanjutnya adalah praktik eksperimen STEAM.

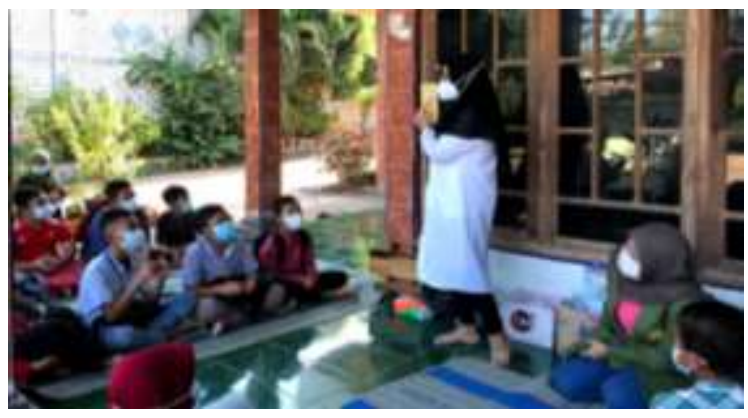

Gambar 3. Pemaparan Materi STEAM

Dalam eksperimen STEAM dipilh tiga percobaan yakni rainbow in the glass, magic candies, dan inflating balloon automatically.

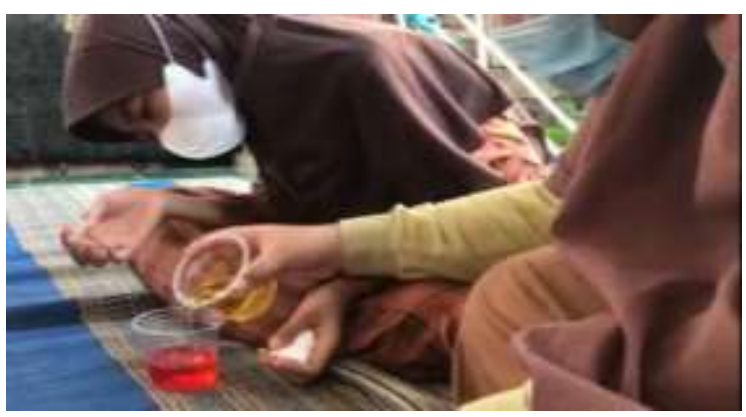

Gambar 4. Percobaan Rainbow in the Glass 


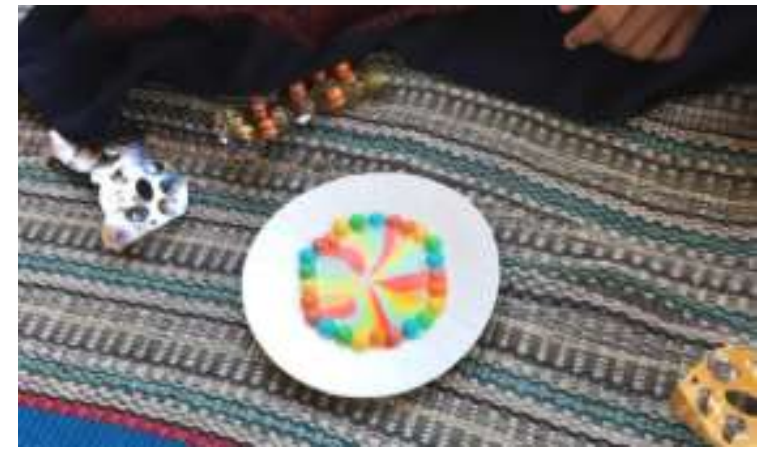

Gambar 5. Percobaan Magic Candies

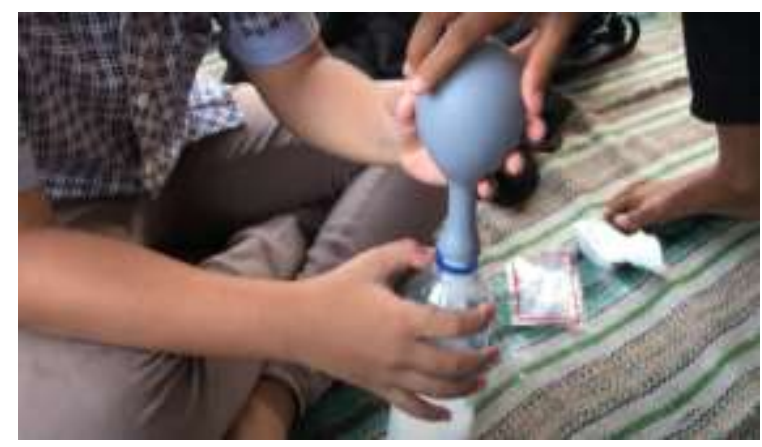

Gambar 6. Percobaan Inflating Balloon Automatically

\section{Pendampingan literasi STEAM}

Pendamping literasi STEAM ditujukan kepada pengurus Panggon Moco yang dipilih untuk menjadi tutor STEAM . Hal ini dilakukan untuk menjamin keberlanjutan program gerakan literasi STEAM ini. Pelaksanaan pendampingan dilakukan secara luring. Selain, pendampingan ini, tim pelaksana juga sudah menyiapkan buku "Fun STEAM Lab" sebagai panduan pelaksanaan STEAM.

Keberhasilan pelaksanaan kegiatan ini diukur dari meningkatnya pemahaman anakanak tentang STEAM, terutama pada percobaan-percobaan yang telah dilakukan. Hal ini terlihat dan diukur dari banyaknya anak yang mampu menjawab dengan benar pertanyaan yang diberikan setelah melakukan percobaan. Hasil ini sejalan dengan penerapan-penerapan STEAM pada anak yang juga memberikan dampak pemahaman literasi sains yang lebih baik setelah penerapan (Afriana, dkk., 2016; Ismail, dkk., 2016; Mufida, dkk., 2020; Pujiati, 2019; Rohmah, dkk., 2019). Selain itu, anak-anak juga sangat antusias mengikuti semua percobaan dengan bimbingan dari tim pelaksana. Ini menunjukkan bahwa minat yang tinggi dari peserta untuk mengikuti kegiatan ini. Hal ini diungkapkan oleh salah seorang peserta, "Saya senang dan pengen ada lagi. Paling suka saya percobaan yang balon.. seru...". Temuan ini sejalan dari hasil penerapan STEAM yang menunjukkan bahwa STEAM meningkatkan minat dan motivasi belajar siswa (Suryaningsih, dkk., 2021).

Kegiatan ini juga mendapatkan respon positif dari pengurus dan masyarakat sekitar. Hal ini diungkapkan ketua Komunitas Panggon Moco yang mengatakan "Kalau menurut saya, acara seperti ini penting sekali, terbukti tadi antusiasme anak-anak. Karena mungkin masa pandemi, jadi anakanak merindukan kegiatan seperti ini, membuat mereka senang. Harapan kami, kegiatan ini tidak hanya sekali, tapi bisa berlanjut, baik online maupun offline."

Secara keseluruhan program ini berhasil dan mendapat dukungan dari banya pihak. Meskipun demikian, beberapa kendala yang dihadapi dalam pelaksanaan program ini dalah kondisi lingkungan yang sedang dilanda wabah covid 19 dan jarak tempuh yang cukup jauh jika dilaksanakan secara luring.

\section{PENUTUP}

\section{Simpulan}

Pelaksanaan gerakan literasi sains melalui pengenalan STEAM pada anak di komunitas "Panggon Moco" Gresik terlaksana secara efektif. Hal ini terlihat dari meningkatnya pemahaman siswa terhadap sains, khususnya berkaitan dengan 
percobaan yang telah dilakukan. Selain itu, program ini mendapatkan apresiasi dan respon positif dari siswa, pengurus "Panggon Moco" dan masyarakat setempat. Dukungan lain dari komunitas Panggon Moco adalah komitmen mereka untuk menerapkan program ini secara berkelanjutan dan terjadwal. Namun demikian, kondisi pandemi covid-19 tidak memungkinkan untuk dilakukan secara terus menerus secara luring.

\section{Saran}

Dengan mempertimbangkan kondisi yang ada, kegiatan tindak lanjut yang perlu dilakukan adalah pendampingan tutor percobaan STEAM dari pengurus atau relawan "Panggon Moco" dan konsep kegiatan dilakukan secara daring.

\section{Ucapan Terima Kasih}

Ucapan terima kasih kepada LPPM UPN Veteran Jawa Timur yang memberikan pendanaan pelaksanaan program pengabdian masyarakat ini dan segenap pengurus TBM "Panggon Moco" Desa Siwalan, Gresik yang memfasilitasi penyelenggaraan program ini.

\section{E. DAFTAR PUSTAKA}

Afriana, J., Permanasari, A., \& Fitriani, A. (2016). Penerapan project based learning terintegrasi STEM untuk meningkatkan literasi sains siswa ditinjau dari gender. Jurnal Inovasi Pendidikan IPA, 2(2), 202-212. https://doi.org/10.21831/jipi.v2i2.85 61

Fazilla, S. (2016). Kemampuan Literasi Sains Mahasiswa PGSD pada Mata Kuliah Konsep Dasar Sains. Jurnal Pendidikan Dasar (JUPENDAS), 3(2), Article 2. http://jfkip.umuslim.ac.id/index.php/j upendas/article/view/220

Hasasiyah, S. H., Hutomo, B. A., Subali, B., \& Marwoto, P. (2020). Analisis Kemampuan Literasi Sains Siswa SMP pada Materi Sirkulasi Darah. Jurnal Penelitian Pendidikan IPA, 6(1), 5-9. https://doi.org/10.29303/jppipa.v6i1. 193

Hidayah, N., Rusilowati, A., \& Masturi, M. (2019). Analisis Profil Kemampuan Literasi Sains Siswa SMP/MTS di Kabupaten Pati. Phenomenon: Jurnal Pendidikan MIPA, 9(1), 3647.

https://doi.org/10.21580/phen.2019.9 .1 .3601

Huryah, F., Sumarmin, R., \& Effendi, J. (2017). Analisis Capaian Literasi Sains Biologi Siswa SMA Kelas X Sekota Padang. JURNAL EKSAKTA PENDIDIKAN (JEP), 1(2), 72-79. https://doi.org/10.24036/jep.v1i2.70

Imaduddin, M. (2017). Mendesain Ulang Pembelajaran Sains Anak Usia Dini yang Konstuktif Melalui Steam Project-Based Learning Yang Bernuansa Islami. Proceedings of Annual Conference for Muslim Scholars, Seri 2, 950-958.

Ismail, I., Permanasari, A., \& Setiawan, W. (2016). Efektivitas virtual lab berbasis STEM dalam meningkatkan literasi sains siswa dengan perbedaan gender. Jurnal Inovasi Pendidikan IPA, 2(2), 190-201. https://doi.org/10.21831/jipi.v2i2.85 70 
Limbong, I., Munawar, M., \& Kusumaningtyas, N. (2019). Perencanaan Pembelajaran PAUD Berbasis STEAM ( Science, Technology, Eingeneering, Art, Mathematics). Seminar Nasional PAUD 2019, 203-212.

Mufida, S. N., Sigit, D. V., \& Ristanto, R. H. (2020). Integrated project-based e-learning with science, technology, engineering, arts, and mathematics (PjBeL-STEAM): Its effect on science process skills. Biosfer: Jurnal Pendidikan Biologi, 13(2), 183-200.

https://doi.org/10.21009/biosferjpb.v $13 \mathrm{n} 2.183-200$

Munawar, M., Roshayanti, F., \& Sugiyanti, S. (2019). Implementation of Steam (Science Technology Engineering Art Mathematics)-Based Early Childhood Education Learning in Semarang City. CERIA (Cerdas Energik Responsif Inovatif Adaptif), 2(5), 276-285. https://doi.org/10.22460/ceria.v2i5.p 276-285

Nofiana, M. (2017). Profil Kemampuan Literasi Sains Siswa SMP di Kota Purwokerto Ditinjau dari Aspek Konten, Proses, dan Konteks Sains. JSSH (Jurnal Sains Sosial Dan Humaniora), 1(2), 77-84. https://doi.org/10.30595/jssh.v1i2.16 82

Nofiana, M., \& Julianto, T. (2018). Upaya Peningkatan Literasi Sains Siswa melalui Pembelajaran Berbasis Keunggulan Lokal. Biosfer: Jurnal Tadris Biologi, 9(1), 24-35. https://doi.org/10.24042/biosf.v9i1.2 876

Novitasari, N. (2018). Profil Kemampuan Literasi Sains Mahasiswa Calon Guru Biologi. Biosfer: Jurnal Tadris Biologi, $\quad 9(1), \quad 36-44$. https://doi.org/10.24042/biosf.v9i1.2 877

Nugraheni, A. D. (2019). Penguatan Pendidikan bagi Generasi Alfa melalui Pembelajaran STEAM Berbasis Loose Parts pada PAUD. Seminar Nasional Pendidikan Dan Pembelajaran 2019, O(0), 512-518.

Nurhikmayati, I. (2019). Implementasi STEAM Dalam Pembelajaran Matematika. Didactical Mathematics, 1(2), Article 2. https://doi.org/10.31949/dmj.v1i2.15 08

OECD. (2019). PISA 2018: Assessment and analytical framework. OECD Publishing.

Pujiati, A. (2019). Peningkatan Literasi Sains dengan Pembelajaran STEM Di Era Revolusi Industri 4.0. Diskusi Panel Nasional Pendidikan Matematika, 5(1), Article 1. http://www.proceeding.unindra.ac.id/ index.php/DPNPMunindra/article/vi ew/3932

Rohmah, U. N., Ansori, Y. Z., \& Nahdi, D. S. (2019). Pendekatan Pembelajaran STEM dalam Meningkatkan Kemampuan Literasi Sains Siswa Sekolah Dasar. Prosiding Seminar Nasional Pendidikan, 1, 471-478. 
Sadiah, N. H., \& Lestari, R. H. (2020). Upaya Meningkatkan Pengetahuan Sains pada Anak Usia Dini melalui Pembelajaran STEAM. CERIA (Cerdas Energik Responsif Inovatif Adaptif), 3(3), 237-244. https://doi.org/10.22460/ceria.v3i3.p 237-244

Suryaningsih, S., Muliharto, \& Nisa, F. A. (2021). Integrasi Science, Technology, Engineering, Art, Mathematics ( STEAM ) Project: Inovasi Pembelajaran Kimia terhadap Minat dan Motivasi Siswa. Prosiding Seminar Nasional "Kurikulum Merdeka BelajarKampus Merdeka,” 222-232. 